\title{
ADDRESS TO THE GRADUATING CLASS, THE FRANKLIN INSTITUTE, SCHOOL OF MECHANIC ARTS.*
}

$\mathrm{BY}$

\section{LOUIS EDWARD LEVY,}

Vice-President of the Institute.

IT is customary, when a class of students is about to be graduated from an institution of learning and its members are leaving to find their places in the world outside, for a speaker to address to the graduates some considerations of the purpose of their studies and some words to remind them that their efforts thus far have been only a preparation for the more strenuous tasks before them, when the knowledge they have acquired from teachers and from books is to be put to use in practical life and their mastery of their subject is to be adjudged, not in the estimates of teachers at the close of school terms, but tested by the value of their service every day, and in examinations more rigorous than any they had gone through in their school days. But the graduation of students from the night schools of the Franklin Institute presents conditions materially different from those which mark a similar occasion in the case of students who have for years been spending all their time in school or college and have thus, as yet, been students only. You members of this present graduating class, and, for that matter, you undergraduates as well, have not to be admonished of what you must expect to deal with in the workday world outside, for all of you are already active in that world and have here been devoting hours, after your daily tasks were done, in an earnest effort to more thoroughly equip yourselves for the work which you were yet to do.

You have here obtained a better understanding of the nature of that work and a fuller knowledge of the ways and means of accomplishing it. You have here learned the principles which are to be applied in your undertaking and have thereby gained a broader view of its meaning and a deeper insight into its purpose. As compared with students who pursue their courses under the seemingly more favorable conditions of uninterrupted study, you have had a great and valuable advantage in learning the science

* Delivered at the closing exercises of the Ninety-third Year of the School, April 20, 1917. 
of your art in the light of your daily practice of it. There is more in this than would appear at first sight, the fact being that not only do the lessons thus learned become clearer to the learner, but also that his everyday experiences are in turn enlightened by his learning.

A course of education which adds to practical work a study of the principles on which its practice is based may well be regared as effective. And, inasmuch as your everday experience hereafter will constantly add to the practical part of your education, it is clear that to keep it effective the other part, in the form of further study, must be added by you as you go along. It is true, indeed, that our daily life is itself a process of education through the lessons of experience, and this is doubly true of those who have studied and continue to study how to better understand those lessons.

The effect of all education, as the word itself signifies, is to bring out from the inner consciousness of the learner his innate capacities of action; in short, as the saying goes, to bring out what is in him. But to bring out the best that is in him the teachings of experience alone are not enough. To that end there is need that the lessons learned through new experiences be combined with those of further study, for without that combination much that is in the learner will become useless through lack of development or worse than useless through a distorted development. It is as when a good planting, for want of cultivation, fails entirely or reaches only a stunted or defective growth. The idea suggested by Alexanter Pope that "a little knowledge is a dangerous thing" but expresses in a terse formula the experience of every generation in every line of endeavor. You have doubtless already found out for yourselves that your studies here are only a beginning, and you will have to keep them up by yourselves if your mastery of your work is to keep pace with its requirements and your sense of proportion (that is to say, your judgment) is to be clarified by your experience.

It has often been remarked that the most that a school can do for its pupils is to teach them knowledge and the rules for applying it, but that the application of their knowledge to conditions which are exceptions to the rules can be learned only in the school of experience. But this is only a half-truth, the fact being that new rules are being made and old ones changed as science and the arts advance, and these advances must be kept 
up with after school days and study continue to go forward with experience. You have had the advantage of pursuing both courses together during the time of your schooling here, and the combined result of your daily experiences and your nightly studies has surely been your acquirement, however, unconsciously, of a capacity for a higher quality of service than could have been attained through either course alone. In all these respects you have but followed in the footsteps of many hundreds of your forerunners for whom the night schools of The Franklin Institute have opened the way to broader fields of endeavor and to larger spheres of usefulness.

Broad as those fields already are, broader than at any time before, they are daily being widened and their scope enlarged by the constant advances of science and the development of the arts. Every new achievement in these ranges of progress opens a vista of other and often greater possibilities beyond, visions which are yet to be realized by further effort directed by just such training as you have received here. There is no field of activity that cannot be enlarged, no addition to our knowledge of Nature's ways that does not offer to the worker an invitation to apply it. The field is open and the invitation is to you.

As I look back across the fifty years and more of my active experience I am impressed with a realizing sense of the fundamental changes which have been brought about within that time in all the various fields of human activity through the revelations of science which have so largely extended our control of the forces of Nature and so greatly widened the scope of the constructive arts. These developments have changed materially the conditions of our daily life, modified greatly our attitude towards surrounding nature, altered in many ways the interrelations of men and ultimately those of nations also. And now, within the short space of your schooling here, the world of human affairs has been going through a violent struggle in the process of its adjustment to these all-pervading changes, like as when an earthquake shakes the land in the course of adjustment to accumulated changes beneath the surface.

It is a struggle in which the course of civilization seems brought to a standstill and in which all the gains of science that make for progress and all the achievements of the arts that signalize it are being diverted from their beneficent purposes and applied to those of ruin and destruction on a scale of unparalleled magni- 
tude. Of the authors of this terrible calamity, of the historic background of the struggle and of its political complications we need not here take account. More insistent, however, upon our immediate consideration is the fact that we here in this western world, where the adjustment of the social structure to changing conditions of life proceeds without violence as occasion for adjustment arises, we here, though far removed from the arena of the struggle and yet farther from its immediate causes, have been forced to take part in it and find ourselves at war. We are forced to take up arms in defence of those ideals of righteousness and freedom which have been the inspiration of our national life from its beginning, the upholding of which has given us leadership in the march of civilization, made our country a beacon-light for all the nations, and centred in it the hopes of all who yearn for right- eousness and freedom throughout the world.

We are all of us called upon to stand together in this defence. We are each of us called upon to do our part in warding off the danger to our welfare and to join with all who in this great war are fighting to prevent the rule of might being made superior to the rule of right, and to put an end to the sway of force in the lands of civilization.

This great war is certain to be followed by a yet greater peace, when the disjointed remnants of the Dark Ages of Europe that yet clutter the roadway of the world's progress will have been swept away and the march of civilization, now so cruelly arrested, will be resumed. It is for you and such as you throughout the land to do your part in the conquering of that peace and in hastening the day when the present revel of destruction will be ended and when you and such as you will be called upon to do the work of reconstruction that is to follow. 